\title{
The Importance of Individual Motivations in Organizational Performance - A Quantitative Study
}

\author{
Pereira, M., Cardoso, A., D’Orey, F., \\ Portugal
}

\begin{abstract}
The choice of this theme arose from the need to understand the communication management in small and medium-sized enterprises in terms of personal and business dynamics, business performance, the personal reputation, proactivity and business dynamics, learning organization and the motivation and personal leadership.
\end{abstract}

We address in this way, the strategy and organizational change, motivation and individual and business needs with regard to capacity building, employee performance and motivation and continuous improvement of business success.

The sample consisted of 388 small and medium enterprises in mainland Portugal. Thus, the assumption of having a probability sample, and considering two times the standard deviation confidence interval, i.e. 95.4\%, have their maximum statistical error $(P=50 \%)$ of $+/-4,95 \mathrm{pp}$

We also sought to study the attitude of managers in the face of market orientation, the behaviors of the organization, attitudes and staff retention, customer satisfaction, employee satisfaction, commitment, involvement, reputation and business performance, the recommendation, business indicators and satisfaction in working in organizations.

We note as well that the relevant aspects for the performance efficiency of employees we can see that the main factors lie in the positive attitude, self-analysis, self-motivation, goal setting, combined with the ability to generate action, comprising the other to be understood in the organization where it operates.

Keywords: strategic communication; business efficiency; communication management; personal leadership.

\section{INTRODUCTION}

The choice of this theme arose from the need to understand the management of communication in small and medium enterprises in terms of personal and business dynamics, business performance, personal reputation, proactivity and business dynamics, the learning organization and the motivation and personal leadership.

The business leadership and success will be addressed at the level of communication and personal leadership, strategy and innovation, business efficiency, business proactivity and dynamic, strategic thinking, business performance and learning organization. In this section we will also lookat the strategy and organizational change, motivation, individual and business needs with regard to capacity development, the performance of employees and their motivation and continuous improvement of business success.

We also sought to study the attitude of managers in the face of market orientation, the behavior of the organization, attitudes and staff retention, customer satisfaction, employee satisfaction, commitment, involvement, business reputation and performance, the recommendation, business indicators and satisfaction in working in organizations

\section{Motivation AND INDIVIDUAL AND BUSINESS NEEDS}

Means for motivation to action, effort, performance plus or supplement a person or a team, according to their skills and competencies taking into account the objectives and needs of an organization.

The motivation of employees is a complex task, since the most assertive way to motivate someone is to help, individually and collectively support employees to disclose and direct their individual skills and competencies recognizing their efforts and contributing to the personal satisfaction according to the organization's vision. 
The major steps of motivation are generally: the existence of unmet needs, tensions and own impulses of this dissatisfaction, the search for behavioral solutions to meet those needs and the reduction of this tension with the resolution of the problem or concern.

On the subject of motivation and characterization, according to Robbins (2009, p 266) we found that; "Hemos definido la motivación como la voluntad para realizar grandes esfuerzos para alcanzar las metas de la organización, a condición de que el esfuerzo pueda satisfacer alguna necesidad personal. En términos menos académicos, la motivación es una función que tiene tres elementos fundamentales: el esfuerzo, las metas de la organización, y las necesidades. Si bien la motivación en general se refiere a un esfuerzo dirigido hacia cualquier meta, en caso se enfoca en las metas de la organización puesto que nuestro punto focal es el comportamiento laboral."

Motivation is the author's words, is the willingness to make great efforts to achieve the organization's goals and thus meet the personal needs of each employee and build a dynamic individual and collective growth, looking for the continuous success of the organization.

We can see that some factors that motivate employees are: the recognition, satisfaction in the work produced, the degree of involvement, economic compensation, the prospect of growth and development in the organization, the trust placed in the person and acceptance of their actions or initiatives in the performance of his activity as a professional.

With regard to the surrounding factors that provide greater motivation of employees we can enumerate: the company culture, personal relationships with other employees, working conditions, the relationship with the leaders, recognition by their peers and by the society in which it operates, security or stability of their employment and prospects for their future.

The pyramid of Maslow's needs begins to be placed in ascending order and pyramidal shape in which the physiological needs, safety, social, esteem and self-actualization. This hierarchy has more applicability in countries where prevalence is North American. On the other hand, in countries with better quality of life, the preponderance focuses on the social needs and the friendly environment throughout the organization.

There are other theories in which the bias is based on self-determination or cognitive assessment where the motivational effects of rewards for the effort and performance of employees are analyzed.

Another theory has the fundamental idea of the theory of goal setting and its projection in productivity which implies internalization by employees in order to fulfill the purposes of the organization.

The explanatory theory offers a real explanation for the issues of productivity, maintaining that the motivation lies in the tendency to act in a certain way and dependent on the expectation that action will be able to attract to the individual.

\subsection{Development of Individual Skills in Business}

Organizations are spaces for sharing and development of skills, managers should encourage learning by promoting creativity and innovation among employees, encouraging the improvement of the capacity to listen, to communicate, to share, to delegate, to manage conflicts, trading and pursue assertive dealings with all employees.

Individual skills are seen as qualities related to the performance of certain tasks or skills. In other words, it is the physical and intellectual characteristics to perform actions or mental activities such as thinking, reasoning and problem solving. In fact all human beings are all different and have weaknesses and strengths that they can enhance.

To better understand the ability of an individual meaning, Robbins (. 2010, p 46) states that: "What is skill? The way we use the term skill refers to the ability of an individual to perform the various tasks of a function. It is an overall assessment of what an individual can do, like playing football, playing the piano, dancing, public speaking and do mathematical calculations. The total skills of a person are usually formed by two groups of factors: Intellectual skills and physical".

According to the author, as already referenced, the term skill is understood as the ability to perform tasks, functions, whether physical or mental. In this sense, the dimensions of intellectual skills are numeracy, verbal comprehension, speed of perception, inductive reasoning, deductive reasoning, spatial visualization and memory. 
Skills aggregate knowledge, skills and attitudes and to that extent if knowledge is acquired at school, in books, on practical experience of everyday life, the skill is knowing how to do, it is the ability to practice and apply knowledge. Attitude is seen as wanting to do, putting into action the three types of knowledge: knowing how to know, how to be and how to do. We can thus infer that more important than having these types of knowledge, it is essential to apply them in practice and above all have a continuous desire or determination to want to do.

To make a difference it is important to build a habit, following an intimate desire, in the words of Covey $(2005$, p. 7), "The habit of following the inner desire to make a difference, to feel that it is taken into account to influence people and causes us to have a particular meaning, invariably it begins with a mental paradigm or ATTITUDE, which is also a choice - the choice to make the voice of influence be heard."

According to Covey, the habit of following the inner desire to make a difference, to feel that they are held in esteem and consideration and to exercise influence over others is fundamental for things to change in line with what each person wants to transform and generate action in others. Therefore, being attitude the ability to influence others we must first be virtuous and reliable to then win the sympathy and respect of others and ultimately be persuasive and consistent in ideas and actions.

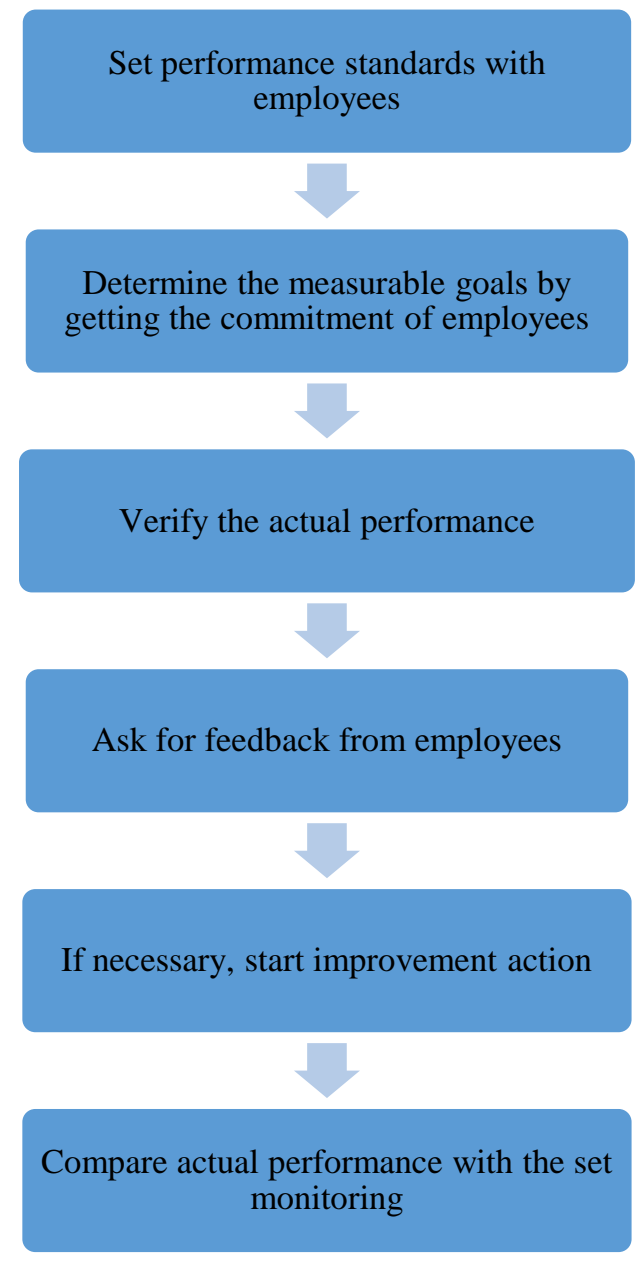

The Evaluation Process

Adapted Robbins (2001, p. 199)

In the author's perspective, the performance evaluation process is based on the definition of performance standards, determining the goals, performance monitoring, feedback request including improvement actions if needed and, finally, to compare the actual performance with what was previously defined.

If there is no one right monitoring to improve or optimize performance, because there are many and varied factors that determine the professional performance, we can enumerate the definition of objectives on the part of business leaders, as well as the definition of an agreement on the respective performance standards, constant monitoring, correction of deviations and / or praise when appropriate are some of the actions carried out in the performance evaluation. 


\subsection{Performance of Employees Working in the Company Service}

Competitive advantage today is characterized not only by financial performance, technology or digital, but mainly by the people who embody the organization, through the responsible and entrepreneurial development in the implementation of the various tasks that incorporate technological innovation, ability to work in partnership, flexibility, knowledge of the mission and goals of the organization itself.

The role of the manager must undertake the implementation of a systemic and comprehensive approach to all employees, promote teamwork, provide a good working environment, manage expectations, encourage initiative and creativity, facilitate communication and individual leadership with the purpose of building a culture of the organization towards excellence.

The main challenges of our time must be consolidated in recognition of the potential of each employee as the most important resource of any organization.

To that extent, it is necessary to involve and engage people, encourage continuous training and development of new skills in accordance with the expectations of stakeholders, create and maintain every effort to uphold a consistent corporate culture and focus all efforts on the consumer public, through monitoring and evaluation of its acceptance or constant satisfaction.

Regarding performance evaluation purposes, Robbins authors Judde \& Sobral (2010, 545 p.) indicate that; "Performance evaluation serves several purposes. One of them is to help the leaders to make various decisions of human resources, such as promotions, transfers and dismissals. The assessments also help organizations identify training and development needs. They identify the skills and competencies of staff for which improvement programs can be developed. Finally, they provide feedback to employees about how the organization sees their work and are used as a basis for the allocation of rewards, including the salary increase."

In the author's words, the performance evaluation is to make decisions in the management of human resources, identify personal and professional development needs and provide the perspective of the organization itself on the performance of employees. We can see that they briefly serve to give feedback, train and prepare the employees and decide on their future in the organization.

At present we can see that the most valued aspects in the evaluation of the performance of the employees hold the most relevant aspects as efficient task performance, which includes responsibility for the performance of their work and contribution to a friendly, empathetic face to co-workers and the organization as a whole. Hence, it is not enough to be competent and professional in carrying out their function, but it is also extremely important the contribution of each to citizenship, involvement and a good working environment.

In the view of these authors Nelo, Francischetto, Souza \& Mahado (2010, p. 5) the current environment of organizations; "This vision will only be complete if, in addition to social, man is considered as a politician (MORETTI, 2003). The environment is multivariate and complex, organizations live in a social human world, political and economic, constantly changing. To better understand what the environment of an organization is, it is necessary to break it down into two segments: the general environment, common to all organizations, and the task environment, which is the specific environment of each organization (Chiavenato, 2004, p. 55).

We can see that according to the authors, the way to better understand the complex environment of organizations is to break it down into general environment and common to all organizations and the task environment that is particular and specific to each one in particular.

Besides this aspect, success in personal performance in organizations depends on the commitment that each employee has to meet personal challenges and interests, as well as the coherence with the goals and interests of the organization. We can say that the degree of efficiency and performance of the specific tasks of an organization depends on the emotional state, level of employee motivation and ultimately the commitment and identification with the values, principles, organizational culture of the organization. 


\subsection{Motivation and Continuous Improvement of Business Success}

We can say that motivation is intrinsic and intrapersonal force that drives a certain behavior and attitude to pursue a task, an action or a set of concerted actions that move an individual to their own life goals, both in the personal context and in the professional context. In this sense, being a man, a social being, reacting or actively acting in contexts where he is inserted in accordance with the feelings, values, principles, circumstances, beliefs, seeking the satisfaction of physiological needs, safety, belonging, consideration and esteem, recognition and personal achievement. Maxwell (2007, p. 393), "It is the greatest folly to talk about motivating someone. The real key is to help others to reveal and guide their deepest motivators. "The process continues when you do what you can to help people to grow and reach their potential. You should do everything possible to see the capabilities of others and help them recognize and develop these capabilities."

According to the author, the most efficient way to motivate someone is to help them, to guide, to reveal and to direct their energies and forces, as well as their potential for growth, taking into account their skills and ultimately help develop these same capabilities always in constant search of continuous improvement.

The great challenge for organizations is to manage the diversity of ideas, feelings, individual perceptions always with the aim to promote creativity and innovation directed to the constant promotion of the general welfare and the organization's own competitiveness. We can say that the success of an organization depends on several factors, such as motivation and commitment of employees, their satisfaction, the dynamics of their leaders, the feedback from stakeholders and the organizational culture that all together is achieved and promoted around the collective whole.

Motivate employees to improve the performance of organizations is according Dantas \& Queiroz (2011, p. 25), and citing the following authors claim; "According WAGNER III and Hollenbeck (2006), to motivate employees to exercise their activities with high levels of performance has been the primary goal of all organizations, while it seeks to find out, how technological advances can be used as a motivational factor to achieve these goals.

The field of organizational behavior, supported with studies and surveys, gives these managers a set of not only effective tools to achieve results in organizations, as well as for development and job satisfaction by the people."

For these authors, motivating staff has been the constant goal of all organizations, as well as understanding how to understand the role of technology as a driving factor of that same motivation to achieve organizational goals.

It is this mediated, trying to understand how the managers and leaders of the organization can use and implement actions or instruments to support the motivation of employees using current technologies, thus improving organizational performance.

On the equitable distribution of rewards, Robbins, Judge \& Sobral (2010, p. 221) indicate that the "evidence meta-analytic also shows that both in individualist cultures as in collectivist, people prefer an equitable distribution of rewards (more efficient workers make more money) than an equal division (everyone receives the same fee regardless of performance)."

In this perspective, and according to the authors, the equitable distribution of rewards, i.e. the better compensation for those who perform better, is one of the factors that people prefer both in individualistic bias organizations and in collectivist organizations. Employees should always be treated and valued in a holistic and comprehensive manner in their personalities as human beings with intelligence and wisdom, understanding their reasons, emotions, feelings, aspirations, in order to be considered as partners, active players in the dynamics of the organization, also being co-responsible for all activities and to that extent, being involved and engaged with all stakeholders provides greater productivity and well-being for the entire organization.

\subsection{Characterization of the Sample}

The final sample consisted of 388 small and medium enterprises of mainland Portugal. Thus, the assumption of having a probability sample, and considering a two times the standard deviation confidence interval, i.e. $95.4 \%$, we have the maximum margin of statistical error $(\mathrm{P}=50 \%)$ of $+/-4$, 95 pp. 
Pereira, M. et al.

\section{EMPloyee Satisfaction (CASe Study)}

Regarding the satisfaction of its employees, what is the degree of correlation with the following statements that are presented.

Employee Satisfaction

\begin{tabular}{|c|c|c|c|c|c|c|c|c|c|c|c|c|}
\hline $\begin{array}{l}\text { Employee } \\
\text { satisfaction }\end{array}$ & & & & & & $\begin{array}{l}\text { ther } \\
\text { e nor } \\
\text { gree }\end{array}$ & & & $\begin{array}{r}\text { Com } \\
\text { a }\end{array}$ & letely & Average & $\begin{array}{r}\text { Standard } \\
\text { deviation }\end{array}$ \\
\hline $\begin{array}{c}\text { Employees of } \\
\text { this company } \\
\text { are satisfied } \\
\text { with the work } \\
\text { they do }\end{array}$ & 0 & 0.0 & 9 & 2.3 & 85 & 21.9 & 179 & 46.1 & 108 & 27.8 & 4.01 & 0.78 \\
\hline $\begin{array}{c}\text { The employees } \\
\text { have good } \\
\text { working } \\
\text { conditions }\end{array}$ & 0 & 0.0 & 15 & 3.9 & 53 & 13.7 & 240 & 61.9 & 77 & 19.8 & 3.98 & 0.70 \\
\hline $\begin{array}{l}\text { I am happy to } \\
\text { be part of this } \\
\text { company }\end{array}$ & 1 & 0.3 & 4 & 1.0 & 45 & 11.6 & 214 & 55.2 & 122 & 31.4 & 4.17 & 0.69 \\
\hline
\end{tabular}

With regard to employee satisfaction, we can see that the answer which received a higher percentage of responses in the "agree" was "the employees have good working conditions" (61.9\%, $\mathrm{M}=3.98, \mathrm{SD}$ $=0.70)$.

Faced with the statement "the employees of this company are satisfied with the work they do," adding the percentages of options "agree and strongly agree" resulted in the following percentages $(66.1+$ 27.8) $=73.9 \% ; \mathrm{F}=04.01 ; \mathrm{SD}=0.78)$.

\subsection{Commitment degree of Employees}

Regarding the satisfaction of employees of a business, what is their degree of agreement with the following statements that are presented.

\section{Employee Commitment}

\begin{tabular}{|c|c|c|c|c|c|c|c|c|c|c|c|c|}
\hline Commitment & \multicolumn{2}{|c|}{$\begin{array}{c}\text { Totally } \\
\text { Disagree }\end{array}$} & \multicolumn{2}{|c|}{$\begin{array}{c}\text { Disagree } \\
\text { agree nor } \\
\text { disagree }\end{array}$} & \multicolumn{2}{c|}{$\begin{array}{c}\text { Neither } \\
\text { Agree }\end{array}$} & \multicolumn{2}{c|}{$\begin{array}{c}\text { Completely } \\
\text { agree }\end{array}$} & Average & $\begin{array}{c}\text { Standard } \\
\text { deviation }\end{array}$ \\
\hline $\begin{array}{c}\text { I recommend the } \\
\text { company's products } \\
\text { or services as the best }\end{array}$ & 0 & 0.0 & 1 & 0.3 & 30 & 7.7 & 230 & 59.3 & 123 & 31.7 & 4.24 & 0.59 \\
\hline $\begin{array}{c}\text { The company I work } \\
\text { for is one of the best } \\
\text { places to work }\end{array}$ & 1 & 0.3 & 23 & 5.9 & 110 & 28.4 & 178 & 45.9 & 69 & 17.8 & 3.76 & 0.83 \\
\hline $\begin{array}{c}\text { There is a fair } \\
\text { exchange between } \\
\text { my contribution and } \\
\text { what the company } \\
\text { invests in me }\end{array}$ & 1 & 0.03 & 28 & 7.2 & 78 & 20.1 & 208 & 53.6 & 66 & 17.0 & 3.81 & 0.81 \\
\hline $\begin{array}{c}\text { I plan to stay in } \\
\text { business at least two } \\
\text { years }\end{array}$ & 1 & 0.3 & 8 & 2.1 & 45 & 11.6 & 198 & 51.0 & 129 & 33.2 & 4.17 & 0.73 \\
\hline
\end{tabular}

With regard to the commitment we can see that the response with more percentage of answers "agree and strongly agree" was "recommend the company's products / services as the best" $(59.3+31.7=$ $91.0 \%, \mathrm{M}=4.24, \mathrm{SD}=0: 59$ ).

In the same vein we have: "There is a fair exchange between my contribution and what the company invests in me" $(53.6+17.0=70.6 \%: \mathrm{M}=4.17 ; 0.73)$.

\subsection{Involvement of Employees}

Data for the involvement of employees is presented in the following table. 


\begin{tabular}{|c|c|c|c|c|c|c|c|c|c|c|c|c|}
\hline \multicolumn{13}{|c|}{ Involvement of Employees } \\
\hline Involvement & \multicolumn{2}{|c|}{$\begin{array}{c}\text { Totally } \\
\text { Disagree }\end{array}$} & \multicolumn{2}{|c|}{ Disagree } & \multicolumn{2}{|c|}{$\begin{array}{l}\text { Neither } \\
\text { agree nor } \\
\text { disagree }\end{array}$} & \multicolumn{2}{|c|}{ Agree } & \multicolumn{2}{|c|}{$\begin{array}{c}\text { Completely } \\
\text { agree }\end{array}$} & Average & $\begin{array}{l}\text { Standard } \\
\text { deviation }\end{array}$ \\
\hline $\begin{array}{c}\text { I am satisfied } \\
\text { with my current } \\
\text { employment }\end{array}$ & 2 & 0.5 & 16 & 4.1 & 42 & 10.8 & 212 & 54.6 & 113 & 29.1 & 4.09 & 0.78 \\
\hline $\begin{array}{l}\text { I am proud to } \\
\text { speak to others } \\
\text { about my } \\
\text { company }\end{array}$ & 1 & 0.3 & 9 & 2.3 & 40 & 10.3 & 205 & 52.8 & 130 & 33.5 & 4.18 & 0.73 \\
\hline $\begin{array}{l}\text { My work is } \\
\text { something that I } \\
\text { really want to do } \\
\text { and not just a } \\
\text { way to earn a } \\
\text { living }\end{array}$ & 1 & 0.3 & 9 & 2.3 & 34 & 8.8 & 216 & 55.7 & 123 & 31.7 & 4.18 & 0.71 \\
\hline $\begin{array}{l}\text { I feel stimulated } \\
\text { and challenged } \\
\text { by my work }\end{array}$ & 2 & 0.5 & 13 & 3.4 & 33 & 8.5 & 216 & 55.7 & 121 & 31.2 & 4.15 & 0.75 \\
\hline
\end{tabular}

With regard to the involvement of employees we found that the most voted responses were: "my work is something I really want to do and not only a means of earning a living" $(55.7 \%, \mathrm{M}=4.18, \mathrm{SD}=$ $0.71)$ "and I feel stimulated and challenged by my work "(55.7\%, M = 4.15, SD = 0.75).

\subsection{Recommendation, Loyalty and Word of Mouth Communication}

Recommendation / loyalty / communication word of mouth

\begin{tabular}{|c|c|c|c|c|c|c|c|c|c|c|c|c|}
\hline $\begin{array}{c}\text { Recommendation / } \\
\text { loyalty / } \\
\text { communication } \\
\text { word of mouth }\end{array}$ & \multicolumn{2}{|c|}{$\begin{array}{c}\text { Totally } \\
\text { Disagree }\end{array}$} & \multicolumn{2}{|c|}{ Disagree } & \multicolumn{2}{|c|}{$\begin{array}{c}\text { Neither } \\
\text { agree nor } \\
\text { disagree }\end{array}$} & \multicolumn{2}{|c|}{ Agree } & \multicolumn{2}{|c|}{$\begin{array}{c}\text { Completely } \\
\text { agree }\end{array}$} & Average & $\begin{array}{l}\text { Standard } \\
\text { deviation }\end{array}$ \\
\hline $\begin{array}{l}\text { I recommend this } \\
\text { company to friends } \\
\text { and family }\end{array}$ & 1 & 0.3 & 5 & 1.3 & 48 & 12.4 & 183 & 47.2 & 144 & 37.2 & 4.22 & 0.73 \\
\hline $\begin{array}{l}\text { I recommend the } \\
\text { company's } \\
\text { products or } \\
\text { services as the best }\end{array}$ & 0 & 0.0 & 1 & 0.3 & 39 & 10.1 & 199 & 51.3 & 145 & 37.4 & 4.27 & 0.65 \\
\hline $\begin{array}{l}\text { I intend to stay in } \\
\text { this company in the } \\
\text { coming years }\end{array}$ & 1 & 0.3 & 11 & 2.8 & 43 & 11.1 & 194 & 50.0 & 134 & 54.5 & 4.17 & 0.76 \\
\hline $\begin{array}{l}\text { I talk about the } \\
\text { company with my } \\
\text { friends and family }\end{array}$ & 0 & 0.0 & 2 & 0.5 & 51 & 13.1 & 199 & 51.3 & 133 & 34.3 & 4.20 & 0.68 \\
\hline
\end{tabular}

On the recommendation / loyalty / mouth communication mouth the answers that obtained equal number of answers were: "I recommend the company's products / services as the best" $(51.3 \%, \mathrm{M}=$ $4.27, \mathrm{SD}=0.73)$ and "I talk about the company to friends and family "(51.3\%, $\mathrm{M}=4.20, \mathrm{SD}=0.68)$.

\subsection{Priority Objectives}

In your opinion, taking into account the priority objectives listed below, which would be those that would be relevant to your company.

Priority objectives

\begin{tabular}{|c|c|c|c|c|c|c|c|c|c|c|c|c|}
\hline $\begin{array}{c}\text { Priority } \\
\text { objectives }\end{array}$ & \multicolumn{2}{|c|}{$\begin{array}{c}\text { Very } \\
\text { irrelevant }\end{array}$} & \multicolumn{2}{|c|}{ Irrelevant } & \multicolumn{2}{|c|}{$\begin{array}{c}\text { Neither } \\
\text { relevant never } \\
\text { irrelevant }\end{array}$} & \multicolumn{2}{|c|}{ Relevant } & Very relevant & Average & $\begin{array}{c}\text { Standard } \\
\text { deviation }\end{array}$ \\
\hline $\begin{array}{c}\text { Reduction in the } \\
\text { number of } \\
\text { complaints }\end{array}$ & 12 & 3.1 & 26 & 6.7 & 56 & 14.4 & 130 & 33.5 & 153 & 39.4 & 4.02 & 1.06 \\
\hline $\begin{array}{c}\text { Improvement of } \\
\text { the productive } \\
\text { process }\end{array}$ & 4 & 1.0 & 19 & 4.9 & 35 & 9.0 & 182 & 46.9 & 140 & 36.1 & 4.14 & 0.86 \\
\hline
\end{tabular}


Pereira, M. et al.

\begin{tabular}{|c|c|c|c|c|c|c|c|c|c|c|c|c|}
\hline $\begin{array}{c}\text { Increase } \\
\text { productivity }\end{array}$ & 2 & 0.5 & 10 & 2.6 & 40 & 10.3 & 170 & 43.8 & 161 & 41.5 & 4.25 & 0.79 \\
\hline $\begin{array}{c}\text { Company image } \\
\text { improvement }\end{array}$ & 5 & 1.3 & 10 & 2.6 & 41 & 10.6 & 204 & 52.6 & 121 & 31.2 & 4.12 & 0.80 \\
\hline $\begin{array}{c}\text { Reduction of } \\
\text { work accidents }\end{array}$ & 47 & 12.1 & 36 & 9.3 & 76 & 19.6 & 95 & 24.5 & 119 & 30.7 & 3.54 & 1.36 \\
\hline $\begin{array}{c}\text { Improvement of } \\
\text { labor relationships }\end{array}$ & 12 & 3.1 & 32 & 8.2 & 61 & 15.7 & 161 & 41.5 & 114 & 29.4 & 3.88 & 1.03 \\
\hline $\begin{array}{c}\text { Improvement of } \\
\text { interpersonal } \\
\text { relationships }\end{array}$ & 7 & 1.8 & 32 & 8.2 & 46 & 11.9 & 191 & 49.2 & 106 & 27.3 & 3.93 & 0.95 \\
\hline $\begin{array}{c}\text { Performance } \\
\text { improvement }\end{array}$ & 5 & 1.3 & 22 & 5.7 & 32 & 8.2 & 189 & 48.7 & 135 & 34.8 & 4.11 & 0.88 \\
\hline $\begin{array}{c}\text { Increased } \\
\text { motivation / } \\
\text { employee } \\
\text { satisfaction }\end{array}$ & 8 & $2-1$ & 18 & 4.6 & 41 & 10.6 & 159 & 41.0 & 159 & 39.7 & 4.14 & 0.94 \\
\hline $\begin{array}{c}\text { Improvement } \\
\text { adaptation to new } \\
\text { tasks }\end{array}$ & 5 & 1.3 & 17 & 4.4 & 48 & 12.4 & 196 & 50.5 & 113 & 29.1 & 4.04 & 0.85 \\
\hline $\begin{array}{c}\text { Improved quality } \\
\text { of service }\end{array}$ & 8 & 2.1 & 10 & 2.6 & 42 & 10.8 & 176 & 45.4 & 147 & 37.9 & 4.16 & 0.87 \\
\hline $\begin{array}{c}\text { Communication } \\
\text { process } \\
\text { improvement }\end{array}$ & 7 & 1.8 & 11 & 2.8 & 50 & 12.9 & 172 & 44.3 & 144 & 37.1 & 4.13 & 0.88 \\
\hline
\end{tabular}

Regarding the priority objectives or those relevant to business, the answers obtained more votes were in the "relevant" option "improving the company's image" $(52.6 \%, \mathrm{M}=4.12, \mathrm{SD}=0.80)$; "Improved adaptation to new tasks" $(50.5 \%, \mathrm{M}=04.04, \mathrm{SD}=0.85)$ and "improvement of interpersonal relationships" (49.2\%, $\mathrm{M}=3.93, \mathrm{SD}=0.95)$.

In the "very relevant" option we can confirm the answers, "increased productivity" ( $41.5 \%, \mathrm{M}=4.25$, $\mathrm{SD}=0.79)$, "increased motivation / employee satisfaction" $(39.7 \%, \mathrm{M}=4.14, \mathrm{SD}=0.94)$ and a decrease in the number of complaints " $(39.4 \%, \mathrm{M}=04.02, \mathrm{SD}=06.01)$. Note that the "reduction of labor accidents" is in the "very irrelevant" $(12.1 \%, \mathrm{M}=3: 54, \mathrm{SD}=1: 56)$.

\subsection{Reputation and Corporate Performance}

How do you rate the performance of the company in the following indicators compared to the average of the companies in its sector.

\section{Reputation and Corporate Performance}

\begin{tabular}{|c|c|c|c|c|c|c|c|c|c|c|c|c|}
\hline $\begin{array}{c}\text { Reputation / } \\
\text { Business } \\
\text { performance }\end{array}$ & \multicolumn{2}{|c|}{$\begin{array}{c}\text { Much lower } \\
\text { than } \\
\text { average }\end{array}$} & \multicolumn{2}{|c|}{$\begin{array}{c}\text { Below the } \\
\text { average }\end{array}$} & \multicolumn{2}{|c|}{$\begin{array}{l}\text { Equal to the } \\
\text { average }\end{array}$} & \multicolumn{2}{|c|}{$\begin{array}{l}\text { Higher than } \\
\text { the average }\end{array}$} & \multicolumn{2}{|c|}{$\begin{array}{c}\text { Much } \\
\text { higher than } \\
\text { the average }\end{array}$} & \multirow{2}{*}{$\begin{array}{c}\text { Average } \\
3.92\end{array}$} & \multirow{2}{*}{\begin{tabular}{|c|}
$\begin{array}{r}\text { Standard } \\
\text { deviation }\end{array}$ \\
0.66 \\
\end{tabular}} \\
\hline $\begin{array}{l}\text { Quality of } \\
\text { products and } \\
\text { services }\end{array}$ & 0 & 0.0 & 4 & 1.0 & 87 & 22.4 & 223 & 57.5 & 65 & 16.8 & & \\
\hline $\begin{array}{c}\text { Quality of } \\
\text { management / } \\
\text { leadership }\end{array}$ & 0 & 0.0 & 18 & 4.6 & 130 & 33.5 & 188 & 48.5 & 38 & 9.8 & 3.66 & 0.73 \\
\hline $\begin{array}{r}\text { Quality of } \\
\text { employees }\end{array}$ & 0 & 0.0 & 13 & 3.4 & 129 & 33.2 & 199 & 51.3 & 38 & 9.8 & 3.69 & 0.70 \\
\hline $\begin{array}{c}\text { Implementation in } \\
\text { national territory }\end{array}$ & 7 & 1.8 & 48 & 12.4 & 170 & 43.8 & 123 & 31.7 & 25 & 6.4 & 3.30 & 0.85 \\
\hline $\begin{array}{c}\text { Social } \\
\text { responsability }\end{array}$ & 1 & 0.3 & 48 & 12.4 & 195 & 50.3 & 110 & 28.4 & 21 & 5.4 & 3.27 & 0.76 \\
\hline Longevity & 2 & 0.5 & 24 & 6.2 & 129 & 33.2 & 174 & 44.8 & 47 & 12.1 & 3.64 & 0.80 \\
\hline Notoriety & 0 & 0.0 & 26 & 6.7 & 126 & 32.5 & 184 & 47.4 & 44 & 11.3 & 3.65 & 0.77 \\
\hline Brand image & 0 & 0.0 & 27 & 7.0 & 108 & 27.8 & 193 & 49.7 & 49 & 12.6 & 3.70 & 0.78 \\
\hline Market share & 9 & 2.3 & 30 & 7.7 & 184 & 47.4 & 122 & 31.4 & 25 & 6.4 & 3.34 & 0.82 \\
\hline Sales volume & 4 & 1.0 & 30 & 7.7 & 180 & 46.4 & 123 & 31.7 & 25 & 6.4 & 3.37 & 0.78 \\
\hline $\begin{array}{c}\text { Global presence } \\
\text { (international } \\
\text { market) }\end{array}$ & 41 & 10.6 & 85 & 21.9 & 105 & 27.1 & 91 & 23.5 & 17 & 4.4 & 2.88 & 1.09 \\
\hline
\end{tabular}


With regard to reputation / business performance we can see that the issues that got more answers in the "above average" were "quality of goods and services" (57.5\%, $\mathrm{M}=3.92, \mathrm{SD}=0.66)$; "Quality management / leadership" (51.3\%, $\mathrm{M}=3.69, \mathrm{SD}=0.70)$ and "brand image" $(49.7 \%, \mathrm{M}=3.70$, $\mathrm{SD}=0.78)$.

On the other hand, one of the aspects to caution is relative to the overall presence (international market) in which "much below average" option obtained: $(21.9 \%, \mathrm{M}=2.88, \mathrm{SD}=09.01)$.

\subsection{Work satisfaction in the Organization}

What is your level of satisfaction in working for this organization.

Degree of Satisfaction in Work in the Organization

\begin{tabular}{|c|c|c|c|c|c|c|c|c|c|c|c|}
\hline \multicolumn{2}{|c|}{$\begin{array}{c}\text { Totally } \\
\text { Disagree }\end{array}$} & \multicolumn{2}{|c|}{ Disagree } & \multicolumn{2}{|c|}{$\begin{array}{l}\text { Neither agree } \\
\text { nor disagree }\end{array}$} & \multicolumn{2}{|c|}{ Agree } & \multicolumn{2}{|c|}{$\begin{array}{c}\text { Completely } \\
\text { agree }\end{array}$} & \multirow{2}{*}{$\begin{array}{c}\text { Average } \\
4.35 \\
\end{array}$} & \multirow{2}{*}{$\begin{array}{c}\begin{array}{c}\text { Standard } \\
\text { deviation }\end{array} \\
0.76 \\
\end{array}$} \\
\hline 5 & 1.3 & 3 & 0.8 & 28 & 7.2 & 163 & 42.0 & 185 & 47.7 & & \\
\hline
\end{tabular}

We can see that in relation to satisfaction of employees in companies we find that the "satisfied" option received (42.0\%) responses and the "very satisfied" relapsed $(47.7 \%, \mathrm{M}=4: 35, \mathrm{SD}=0.76)$.

\section{Conclusion}

With regard to the development of individual skills these are based personal pro activity at the level of ability to communicate, share and ultimately get a positive feedback from partners.

Taking into account the relevant aspects for the performance efficiency of employees we can see that the main factors reside in positive attitude, self-analysis, self-motivation, goal setting, combined with the ability to generate action, comprising others to be understood in the organization where they are inserted.

If success is somewhat idiosyncratic in that it depends on the objectives of the organization it must be taken into account the size, motivation and engagement, as well as the culture of each organization. Whereas motivation is something intrinsic to each individual that can and should be assisted by the team.

The role of the leader in organizations is of extreme importance, mediated in which the leader must instill confidence, ambition, positive attitude, understanding, efficient management of expectations by example and. essentially, the ability to inspire and generate new leaders with creativity, innovation and self-leadership, without forgetting the collective vision of the organization itself.

In conclusion, the efficient management of communication in organizations is a key factor to facilitate interactivity, mutual understanding and individual empowerment continuously looking for dynamic synergies able to instill an organizational climate in constant harmony with the strategic vision of the organization itself.

\section{REFERENCES}

Covey, S. R. (2005). The 8th Habit: efficiency to greatness. Lisbon: Ed Dinalivro.

Dantas, H.S. \& Queiroz, F.C. (2011). Organizational Behavior: creating competitive advantage. Accessed November 21, 2013 in http://www.fibrapara.edu.br/seer/ojs/index.php/fibra_e_ciencia /article/view/55/49

Maxwell, J.C. (2007). Talent is not everything: discover the 13 principles to overcome their talents and maximize their skills. Ed. Smartbook.

Nelo, S.T.B., Francischetto, MA, Souza, S. \& Machado, M. T. (2010). Motivation and enhancement of intellectual capital in the context of the knowledge society. In VII Symposium on Excellence in Management and Technology, Rio de Janeiro, 23-25 October, 2010.

Robbins, S. P. (2008). The secret in people management. Lisbon: Ed Atlantic Center.

Robbins, S. P. (2009). administración Fundamentals (6ND ed.). Mexico: Ed Pearson Educación.

Robbins, S. P., Judge A. T., \& Sobral, F. (2011). Organizational behavior (14end ed.). São Paulo: Ed Pearson Prentice Hall.

Robbins, S. P., Judge, T. Sobral, F. (2010). Organizational behavior: theory and practice in the Brazilian context. São Paulo: Ed Pearson Prentice Hall.

Robbins, S. P., Judge, T. Sobral, F. (2010). Organizational behavior: theory and practice in the Brazilian context. São Paulo: Ed Pearson Prentice Hall. 


\section{AUTHORS' BIOGRAPHY}

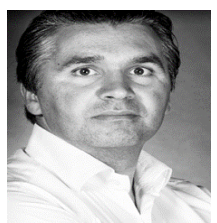

Manuel Sousa Pereira, PhD in Communication Sciences, Master in Communication and Journalism from the University of Santiago de Compostela, Master in Marketing and Strategic Communication and BA in Public Relations from the University Fernando Pessoa.

Professor and member of the Higher Pedagogical Council of Business School of the Polytechnic Institute of Viana do Castelo.

Trainer and consultant for more than 18 years in the areas of communication, marketing, advertising, public relations, advertising, event organization, sales, service and negotiation in companies and institutions in Northern Portugal.

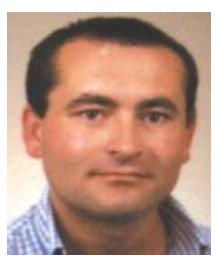

António Cardoso, Master in Design \&Marketing (U. Minho), and $\mathrm{PhD}$ in Engineering: Management and Design (U. Minho). He is Assistant Professor of the Faculty of Humanities and Social Sciences at the University Fernando Pessoa (Porto, Portugal), Department of Communication and Department of Business Sciences, where teaches in the areas of Communication, Marketing and Management, and coordinates the following programs studies: Bachelor and Master's Degrees in Business Sciences, Bachelor in Management and Accounting, MBA in Business Sciences, PG in Design and Innovation.

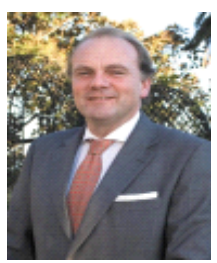

Frederico Guilherme d'Orey, $\mathrm{PhD}$ in Entrepreneurial Sciences, with 30 years of professional experience at high management levels, in companies and institutions of national and international reference.

Professional experience reaches a especial relevancy at the 11 years at the service of the automotive industry, having executed functions of marketing management at BMW, AUDI and MAZDA; 5 years at the Portugal Ministry of Economics at ICEP (Portugals Tourism Commerce and Investment, having played during that period the role of technical responsible of the Portugal brand, and coordinated the international tourism advertising campaigns for Portugal.

Since September 2015, is Teacher at Portucalense University in Porto Portugal. 